\title{
Effect of tree pruning intensity on the content of mineral components in the sour cherry leaves of 'Lutówka'
}

\author{
Krzysztof Rutkowski*, Zofia Zydlik, Aleksander Stachowiak \\ Department of Dendrology, Pomology and Nursery \\ University of Life Sciences \\ Dąbrowskiego 159, 60-594 Poznań, Poland
}

\begin{abstract}
The aim of the study was to estimate the effect of' tree pruning intensity on the content of nutrients in leaves of the 'Eutówka' sour cherry cultivar (Prunus cerasus L.). Between 2006 and 2010 an experiment with different tree pruning intensity was carried out. The study material consisted of first- class one-year old budded plants of the 'Lutówka' cultivar IR2 type, on Prunus mahaleb rootstock. The plants were planted in the spring of 2001 (orchard 1) and 2002 (orchard 2) and spaced at $4.0 \times 1.3 \mathrm{~m}^{2}$, giving a total of 1.920 trees ha' ${ }^{-1}$ Three pruning regimes were applied in the plantation: 1) no pruning; (only sanitation felling was applied), 2) moderate traditional pruning - branches were shortened, 3) intensive pruning by removing branches older than three years. The cherry tree pruning intensity significantly influenced the content of mineral components in leaves. The content of $\mathrm{N}$ increased, whereas the content of $\mathrm{Ca}$ and $\mathrm{Mg}$ decreased. The maximum temperatures at the beginning of the growth period had particularly beneficial effect on the $\mathrm{P}$ and $\mathrm{K}$ content. Chilly and dry spring limited the $\mathrm{P}$ and $\mathrm{K}$ content in the plants. The content of minerals in sour cherry leaves depended on the age of trees.
\end{abstract}

Keywords: crown form, leaf analysis, nutrients, pruning, Prunus cerasus L.

\section{INTRODUCTION}

Poland is one of the biggest cherry producers (GUS, 2016; FAOSTAT, 2017). However, the profitability of production has decreased due to labour costs, which can amount up to $70 \%$ of total costs (Brzozowski and Zmarlicki, 2011). Therefore, we considered the method of shaping the tree crown to reduce labour costs, as it would give a possibility to increase production intensity and apply continuous combine harvesting (Mika et al., 2011b). Widely spaced cherry trees pruned in a traditional way tend to be stunted and without a leader branch. Mika et al. (2011b) noted that appropriately shaped tree crowns may increase the profitability of production and automate harvesting. In many countries with intensive cherry orchard systems there are good results of shaping tree crowns in the tall spindle or axial system (Mika et al., 2011a; Mika et al., 2011b; Hrotkó, 2013). A tree will give a high yield only if there are a lot of fruit-bearing sprouts in its crown. The 'Łutówka' cultivar is predominant in Polish commercial production. It is characterised by a specific growth pattern (Rutkowski et al., 2015). Trees have round crowns with bare sprouts outside the crown. Traditional tree pruning makes it impossible to plant trees at high density and apply continuous mechanical harvesting. It is only possible by introducing appropriate tree crown systems, e.g. the tall spindle tree system, which

*Corresponding author. 
increases the production intensity and reduces costs (Mika at al., 2011b).

Nutrition is an important determinant of yield but there are numerous factors which influence the content of nutrients in a plant. Their sufficient amounts are defined as adequate or normal. Appropriate amounts of nutrients result in higher productivity and yield quality. Excess of nutrients causes imbalance of the plant mineral status and may cause toxicity symptoms. Plants will develop at a slower rate or show symptoms of nutrient excess or deficiency (Tsai, 2015). It is necessary to know the limit values of the content of mineral components in leaves and in soil to interpret results correctly (Sadowski et al., 1990; Rowley, 2013). These values depend on the species, cultivar, phase of development, rootstock, thinning and pruning method, the weather conditions in the growing season and other minor factors (Dencker and Toldam-Andersen, 2005; Pietranek and Jadczuk, 2005; Krishkov, 2007; Nagy at al., 2007; Zydlik and Pacholak, 2007; Lang at al., 2011; Mikiciuk et al., 2013). Zydlik et al. (2006a) researched the influence of nitrogen fertilisation on the content of nutrients in 'Łutówka' cherry leaves. Fertilisation increased the nitrogen content but decreased the phosphorus content in the leaves. It did not have significant influence on the content of other components. Pruning intensity affected tree nutrition. It decreased the content of phosphorus, magnesium and calcium, but increased the content of nitrogen (Zydlik et al., 2006b). The content of nutrients in leaves also depends on the age of trees and climate (Treder and Olszewski, 2004; Zydlik et al., 2006a). Pietranek and Jadczuk (2005) studied the influence of irrigation on the level of nutrition of 'Katja' apple trees and found that it did not have significant influence on the content of macronutrients in leaves.

The research conducted by Milošević et al. (2012) indicated that the content of Mn influenced the length of plum shoots. There were significant relationships observed between the leaf $\mathrm{Fe}$ concentration and fruit weight. However, the increase in the $\mathrm{N}$ content in leaves was negatively correlated with the yield. Mestre et al. (2017) also reported significant negative correlations between the leaf $\mathrm{N}$ concentration and fruit soluble solid content. However, Jiménez et al. (2007) also reported significant positive correlations between the yield and the content of $\mathrm{Mn}$, except $\mathrm{Ca}$ and $\mathrm{Mg}$, which showed negative correlations.
This study was conducted because there is little information how the intensity of pruning sour cherry trees affects the content of nutrients in leaves.

One aim of the study was to assess how the pruning of trees at different ages influenced the mineral content in leaves. The other aim of the study was to assess the influence of cherry tree pruning on the content of nutrients in leaves.

\section{MATERIAL AND METHODS}

The study was conducted between 2006 and 2010 at the Research Station of the Poznan University of Life Sciences located in Przybroda, Poland. 'Lutówka' sour cherry trees, IR type on Prunus mahaleb rootstock were planted in spring 2001 (orchard 1) and 2002 (orchard 2). The trees were planted in grey-brown podzol overlaying light boulder clay and they were spaced at $4 \times 1.3 \mathrm{~m}^{2}$ (1.920 trees $\left.\mathrm{ha}^{-1}\right)$. The arable layer was composed of medium sand and the sub-arable layer was fine sandy loam. At a depth of 150-160 cm there was sandy loam. The ground water level was maintained at about $180 \mathrm{~cm}$.

Before the trees were planted the soil had been deep-ploughed and fertilised with $40 \mathrm{t}$ of farmyard manure, $200 \mathrm{~kg}$ of $\mathrm{K}_{2} \mathrm{O} \mathrm{ha}{ }^{-1}$ (potash salt) and $185 \mathrm{~kg}$ of $\mathrm{P}_{2} \mathrm{O}_{5} \mathrm{ha}^{-1}$ (triple superphosphate) in autumn. Previously, other crops had been grown in the field. In the last year before the research wheat had been grown.

The trial was a two-factor experiment. The first factor was the date of tree planting (spring 2001 - orchard 1, spring 2002 - orchard 2). The other factor comprised three pruning regimes: 1) no pruning; only sanitary felling was applied, 2) moderate traditional pruning where branches were shortened by $1 / 3$ of their length, 3 ) intensive pruning by removing branches older than 3 years. There were 4 replicates in each combination, with ten trees in one replicate.

In each year of the experiment ammonium nitrate was applied during the first ten days of April. The orchard management (pest and disease control, fertilisation and weed control) was in line with the recommendations for commercial orchards. Mechanical black fallow with herbicide fallow in tree rows was the orchard soil cultivation system. After harvesting fruit leaf and soil samples were collected for analysis. Each year soil samples from the herbicide strips of each plot were collected with a soil drill, separately from the layers of $0-20$ and $20-40 \mathrm{~cm}$. The soil abundance in nutrients was estimated according to the Egner-Riehm ( $\mathrm{P}$ and 
Table 1. Content of mineral components in the soil in 2006-2010 (mg $100 \mathrm{~g}^{-1}$ soil)

\begin{tabular}{|c|c|c|c|c|c|c|c|c|c|c|c|}
\hline \multirow{3}{*}{ Year } & \multirow{3}{*}{ Orchard } & \multicolumn{10}{|c|}{ Soil layers } \\
\hline & & \multicolumn{5}{|c|}{$0-20 \mathrm{~cm}$} & \multicolumn{5}{|c|}{$21-40 \mathrm{~cm}$} \\
\hline & & $\mathrm{P}$ & $\mathrm{K}$ & $\mathrm{Mg}$ & $\mathrm{pH}_{\mathrm{KCl}}$ & $\mathrm{K} / \mathrm{Mg}$ & $\mathrm{P}$ & $\mathrm{K}$ & $\mathrm{Mg}$ & $\mathrm{pH}_{\mathrm{KCl}}$ & $\mathrm{K} / \mathrm{Mg}$ \\
\hline \multirow{2}{*}{2006} & Orchard 1 & 6.9 & 7.6 & 11.4 & 6.2 & 0.7 & 6.6 & 6.5 & 9.3 & 5.9 & 0.7 \\
\hline & Orchard 2 & 9.5 & 12.3 & 12.6 & 6.2 & 1.0 & 8.8 & 8.5 & 10.2 & 6.1 & 0.8 \\
\hline Mean & & 8.2 & 10.0 & 12.0 & 6.2 & 0.8 & 7.7 & 7.5 & 9.7 & 6.0 & 0.8 \\
\hline \multirow{2}{*}{2007} & Orchard 1 & 8.1 & 8.7 & 10.9 & 6.4 & 0.8 & 7.6 & 9.2 & 10.0 & 6.5 & 0.9 \\
\hline & Orchard 2 & 9.5 & 13.0 & 12.4 & 6.4 & 1.0 & 7.6 & 12.0 & 10.8 & 6.3 & 1.1 \\
\hline Mean & & 8.8 & 10.8 & 11.6 & 6.4 & 0.9 & 7.6 & 10.6 & 10.4 & 6.4 & 1.0 \\
\hline \multirow{2}{*}{2008} & Orchard 1 & 6.9 & 7.4 & 8.9 & 6.5 & 0.8 & 6.2 & 6.2 & 7.9 & 6.3 & 0.8 \\
\hline & Orchard 2 & 6.9 & 7.4 & 10.5 & 6.2 & 0.7 & 3.4 & 5.3 & 11.5 & 6.1 & 0.5 \\
\hline Mean & & 6.9 & 7.4 & 9.7 & 6.4 & 0.8 & 4.8 & 5.8 & 9.7 & 6.2 & 0.6 \\
\hline \multirow{2}{*}{2009} & Orchard 1 & 7.5 & 10.6 & 11.3 & 6.6 & 0.9 & 7.5 & 6.8 & 8.9 & 6.4 & 0.8 \\
\hline & Orchard 2 & 10.2 & 7.1 & 11.7 & 6.4 & 0.6 & 4.2 & 3.6 & 10.6 & 6.4 & 0.3 \\
\hline Mean & & 8.9 & 8.9 & 11.5 & 6.5 & 0.8 & 5.9 & 5.2 & 9.8 & 6.4 & 0.5 \\
\hline \multirow{2}{*}{2010} & Orchard 1 & 9.0 & 10.2 & 11.6 & 6.6 & 0.9 & 6.8 & 8.4 & 9.0 & 6.1 & 0.9 \\
\hline & Orchard 2 & 10.1 & 7.4 & 11.6 & 7.1 & 0.6 & 5.2 & 5.2 & 9.2 & 6.6 & 0.6 \\
\hline Mean & & 9.6 & 8.8 & 11.6 & 6.9 & 0.8 & 6.0 & 6.8 & 9.1 & 6.3 & 0.8 \\
\hline
\end{tabular}

$\mathrm{K})$ and Schachtschabel $(\mathrm{Mg})$ methods. On average there were 150-200 leaves from each plot in one sample. 15-20 leaves were collected from one tree. They came from the mid-portion of extension shoots of the current year's growth, located outside the tree canopy, 1.5-2.0 $\mathrm{m}$ above the ground. The leaves were dried at $70^{\circ} \mathrm{C}$, ground, and wet burnt. The contents of $\mathrm{K}$ and $\mathrm{Mg}$ were measured with an atomic absorption spectrometer, calcium - by means of atomic absorption with lanthanum concentrated at $1 \%$. The $\mathrm{P}$ content was measured calorimetrically with a molybdenum-vanadium mixture. The total nitrogen level was measured with the Kjeldhal method (Ostrowska et al., 1991).
The results were compared with the critical levels of nutritive components in leaves, developed by Sadowski et al. (1990).

The meteorological data covering the period of the experiment and the long-term period of 19822010 were collected from the Weather Research Station in Przybroda.

The effects of environmental factors on the content of macronutrients, $\mathrm{pH}$ and the $\mathrm{K} / \mathrm{Mg}$ ratio in leaves were evaluated by calculating linear correlations between the mineral content in the soil (Tab. 1), mean temperature, total rainfall during the growth season and the mineral content in the leaves.

Table 2. Characteristics of average temperatures and precipitation totals in 2006-2010 from Weather Research Station located in Przybroda

\begin{tabular}{|c|c|c|c|c|}
\hline Years & $\begin{array}{c}\text { Average annual } \\
\text { temperature } \\
\left({ }^{\circ} \mathrm{C}\right)\end{array}$ & $\begin{array}{l}\text { Average temperature } \\
\text { during the growing } \\
\text { season } \\
\text { April-September } \\
\left({ }^{\circ} \mathrm{C}\right)\end{array}$ & $\begin{array}{l}\text { Total annual } \\
\text { precipitation } \\
(\mathrm{mm})\end{array}$ & $\begin{array}{l}\text { Precipitation sum of } \\
\text { the growing season } \\
\text { April-September } \\
\text { (mm) }\end{array}$ \\
\hline $\begin{array}{l}\text { Average for Przybroda } \\
\text { 1982-2010 }\end{array}$ & 9.0 & 15.5 & 517.8 & 327.1 \\
\hline 2006 & 9.3 & 15.6 & 424.7 & 324.1 \\
\hline 2007 & 9.2 & 14.0 & 575.8 & 370.0 \\
\hline 2008 & 9.2 & 13.8 & 511.6 & 343.0 \\
\hline 2009 & 8.4 & 13.9 & 628.8 & 498.0 \\
\hline 2010 & 7.5 & 13.9 & 698.0 & 455.3 \\
\hline $\begin{array}{l}\text { Average } \\
2006-2010\end{array}$ & 8.7 & 14.2 & 567.8 & 398.1 \\
\hline
\end{tabular}


The results were processed statistically, using the analysis of variance for each year separately and for the total period of the experiment. The Duncan test with the assumed significance level of $5 \%$ was used to assess differences between the mean values.

The meteorological data covering the period of the experiment (2006-2010) varied greatly. The average annual temperatures in the first three years were higher than the multiannual average, but in the following two years they were $0.6^{\circ} \mathrm{C}$ and $1.5^{\circ} \mathrm{C}$ lower than the average. Consequently, the average annual temperatures during the study were $0.3^{\circ} \mathrm{C}$ lower than the multiannual average temperature. Similarly, the average temperature during the growing season was $1.3^{\circ} \mathrm{C}$ lower than the multiannual average in the period of 1982-2010. Only in 2006 it reached $15.6^{\circ} \mathrm{C}$, which was slightly higher than average (Tab. 2).

The total rainfall in the growing season (AprilSeptember) was higher than the multiannual average. Between 2006 and 2008 the annual rainfall was medium, but between 2009 and 2010 it was high. During the period of the experiment, both in the growing season (April-September) and during the whole year the rainfall was higher than the multiannual average (Tab. 2).

There was a regularity - the higher the total annual rainfall was, the lower the average temperature was.

\section{RESULTS AND DISCUSSION}

The cherry tree pruning methods applied in the experiment and the weather conditions in the growing season during the study influenced the content of macronutrients in leaves.

Between 2006 and 2010 the nitrogen content in the system without pruning was lower than in the intensive pruning system (Tab. 3). It amounted to $2.13 \%$ and $2.18 \%$ of dry matter, respectively, in the orchard planted in 2001 and 2002. Our results

Table 3. Effect of pruning and orchard on macro nutrients ( $\%$ DW) in leaves of sour cherry trees

\begin{tabular}{|c|c|c|c|}
\hline \multirow{2}{*}{ Pruning } & \multicolumn{2}{|c|}{ Year of planting } & \multirow[t]{2}{*}{ Mean of pruning } \\
\hline & 2001 & 2002 & \\
\hline \multicolumn{4}{|c|}{$\mathrm{N}$} \\
\hline Without cutting & $2.13 \mathrm{a}$ & $2.18 \mathrm{ab}$ & $2.15 \mathrm{a}$ \\
\hline Moderate traditional pruning & $2.16 \mathrm{ab}$ & $2.26 \mathrm{bc}$ & $2.21 \mathrm{ab}$ \\
\hline Intensive pruning & $2.22 \mathrm{ab}$ & $2.33 \mathrm{c}$ & $2.27 \mathrm{~b}$ \\
\hline Mean of year planting & $2.17 \mathrm{~A}$ & $2.25 \mathrm{~B}$ & \\
\hline \multicolumn{4}{|c|}{$\mathrm{P}$} \\
\hline Without cutting & $0.24 \mathrm{a}$ & $0.26 \mathrm{a}$ & $0.25 \mathrm{a}$ \\
\hline Moderate traditional pruning & $0.24 \mathrm{a}$ & $0.24 \mathrm{a}$ & $0.24 \mathrm{a}$ \\
\hline Intensive pruning & $0.23 \mathrm{a}$ & $0.25 \mathrm{a}$ & $0.24 \mathrm{a}$ \\
\hline Mean of year planting & $0.24 \mathrm{~A}$ & $0.25 \mathrm{~A}$ & \\
\hline \multicolumn{4}{|c|}{$\mathrm{K}$} \\
\hline Without cutting & $1.12 \mathrm{ab}$ & $1.10 \mathrm{ab}$ & $1.11 \mathrm{a}$ \\
\hline Moderate traditional pruning & $1.05 \mathrm{a}$ & $1.16 \mathrm{ab}$ & $1.10 \mathrm{a}$ \\
\hline Intensive pruning & $1.12 \mathrm{ab}$ & $1.24 \mathrm{~b}$ & $1.18 \mathrm{~b}$ \\
\hline Mean of year planting & $1.10 \mathrm{~A}$ & $1.17 \mathrm{~A}$ & \\
\hline \multicolumn{4}{|c|}{$\mathrm{Ca}$} \\
\hline Without cutting & $2.70 \mathrm{ab}$ & $2.87 \mathrm{~b}$ & $2.79 \mathrm{~b}$ \\
\hline Moderate traditional pruning & $2.47 \mathrm{a}$ & $2.65 \mathrm{ab}$ & $2.56 \mathrm{a}$ \\
\hline Intensive pruning & $2.44 \mathrm{a}$ & $2.54 \mathrm{a}$ & $2.49 \mathrm{a}$ \\
\hline Mean of year planting & $2.54 \mathrm{~A}$ & $2.69 \mathrm{~B}$ & \\
\hline \multicolumn{4}{|c|}{$\mathrm{Mg}$} \\
\hline Without any cutting & $0.64 \mathrm{~b}$ & $0.61 \mathrm{a}$ & $0.63 \mathrm{a}$ \\
\hline Moderate traditional pruning & $0.62 \mathrm{ab}$ & $0.61 \mathrm{a}$ & $0.62 \mathrm{a}$ \\
\hline Intensive pruning & $0.58 \mathrm{a}$ & $0.60 \mathrm{a}$ & $0.59 \mathrm{a}$ \\
\hline Mean of year planting & $0.62 \mathrm{~A}$ & $0.61 \mathrm{~A}$ & \\
\hline
\end{tabular}

"Means marked by the same letters are not significant at the $p \leq 0.05$ 
Table 4. Effect of pruning on macro nutrients (\% DW) in leaves of sour cherry trees planted in 2001

\begin{tabular}{|c|c|c|c|c|c|}
\hline \multirow{2}{*}{ Pruning } & \multicolumn{5}{|c|}{ Year of leaves analyses } \\
\hline & 2006 & 2007 & 2008 & 2009 & 2010 \\
\hline & \multicolumn{5}{|c|}{$\mathrm{N}$} \\
\hline Without cutting & $2.22 \mathrm{a}^{*}$ & $2.19 \mathrm{a}$ & $2.02 \mathrm{a}$ & $2.26 \mathrm{a}$ & $1.96 \mathrm{a}$ \\
\hline Moderate traditional pruning & $2.32 \mathrm{a}$ & $2.14 \mathrm{a}$ & $2.13 \mathrm{ab}$ & $2.15 \mathrm{a}$ & $2.07 \mathrm{a}$ \\
\hline Intensive pruning & $2.34 \mathrm{a}$ & $2.22 \mathrm{a}$ & $2.23 \mathrm{~b}$ & $2.21 \mathrm{a}$ & $2.10 \mathrm{a}$ \\
\hline \multirow[t]{2}{*}{ Mean of pruning } & $2.29 \mathrm{c}$ & $2.18 \mathrm{~b}$ & $2.13 \mathrm{ab}$ & $2.21 \mathrm{~b}$ & $2.05 \mathrm{a}$ \\
\hline & \multicolumn{5}{|c|}{$\mathrm{P}$} \\
\hline Without cutting & $0.21 \mathrm{a}$ & $0.22 \mathrm{a}$ & $0.26 \mathrm{a}$ & $0.25 \mathrm{a}$ & $0.24 \mathrm{a}$ \\
\hline Moderate traditional pruning & $0.19 \mathrm{a}$ & $0.21 \mathrm{a}$ & $0.26 \mathrm{a}$ & $0.30 \mathrm{a}$ & $0.26 \mathrm{a}$ \\
\hline Intensive pruning & $0.19 \mathrm{a}$ & $0.21 \mathrm{a}$ & $0.25 \mathrm{a}$ & $0.26 \mathrm{a}$ & $0.22 \mathrm{a}$ \\
\hline \multirow[t]{2}{*}{ Mean of pruning } & $0.20 \mathrm{a}$ & $0.21 \mathrm{a}$ & $0.26 \mathrm{bc}$ & $0.27 \mathrm{c}$ & $0.23 \mathrm{~b}$ \\
\hline & \multicolumn{5}{|c|}{$\mathrm{K}$} \\
\hline Without cutting & $1.00 \mathrm{~b}$ & $1.05 \mathrm{a}$ & $0.98 \mathrm{a}$ & $1.34 \mathrm{a}$ & $1.24 \mathrm{a}$ \\
\hline Moderate traditional pruning & $0.87 \mathrm{a}$ & $0.91 \mathrm{a}$ & $0.99 \mathrm{a}$ & $1.29 \mathrm{a}$ & $1.18 \mathrm{a}$ \\
\hline Intensive pruning & $0.95 \mathrm{ab}$ & $1.01 \mathrm{a}$ & $1.13 \mathrm{a}$ & $1.28 \mathrm{a}$ & $1.21 \mathrm{a}$ \\
\hline \multirow[t]{2}{*}{ Mean of pruning } & $0.94 \mathrm{a}$ & $0.99 \mathrm{a}$ & $1.03 \mathrm{a}$ & $1.30 \mathrm{~b}$ & $1.21 \mathrm{~b}$ \\
\hline & \multicolumn{5}{|c|}{$\mathrm{Ca}$} \\
\hline Without cutting & $2.66 \mathrm{a}$ & $2.30 \mathrm{a}$ & $3.24 \mathrm{~b}$ & $2.61 \mathrm{a}$ & $2.71 \mathrm{~b}$ \\
\hline Moderate traditional pruning & $2.67 \mathrm{a}$ & $2.25 \mathrm{a}$ & $2.64 \mathrm{a}$ & $2.42 \mathrm{a}$ & $2.37 \mathrm{a}$ \\
\hline Intensive pruning & $2.56 \mathrm{a}$ & $2.13 \mathrm{a}$ & $2.75 \mathrm{ab}$ & $2.56 \mathrm{a}$ & $2.19 \mathrm{a}$ \\
\hline \multirow[t]{2}{*}{ Mean of pruning } & $2.63 \mathrm{~b}$ & $2.23 \mathrm{a}$ & $2.88 \mathrm{c}$ & $2.53 \mathrm{~b}$ & $2.42 \mathrm{ab}$ \\
\hline & \multicolumn{5}{|c|}{$\mathrm{Mg}$} \\
\hline Without any cutting & $0.64 \mathrm{de}$ & $0.57 \mathrm{a}$ & $0.79 \mathrm{~b}$ & $0.60 \mathrm{a}$ & $0.63 \mathrm{~b}$ \\
\hline Moderate traditional pruning & $0.63 \mathrm{~cd}$ & $0.56 \mathrm{a}$ & $0.76 \mathrm{ab}$ & $0.59 \mathrm{a}$ & $0.60 \mathrm{~b}$ \\
\hline Intensive pruning & $0.60 \mathrm{~b}-\mathrm{d}$ & $0.53 \mathrm{a}$ & $0.70 \mathrm{a}$ & $0.56 \mathrm{a}$ & $0.52 \mathrm{a}$ \\
\hline Mean of pruning & $0.62 \mathrm{~b}$ & $0.55 \mathrm{a}$ & $0.75 \mathrm{c}$ & $0.58 \mathrm{ab}$ & $0.58 \mathrm{ab}$ \\
\hline
\end{tabular}

"Means marked by the same letters are not significant at the $p \leq 0.05$

were in agreement with the findings of the study by Zydlik et al. (2006b), who noted that the pruning of cherry trees between 2003 and 2005 significantly increased the $\mathrm{N}$ content in leaves. However, in our study the $\mathrm{N}$ content also depended on the conditions in the growing season. Regardless of the pruning intensity, the $\mathrm{N}$ content was lower in orchard 1 (Tab. 3). It is noteworthy that the $\mathrm{N}$ content decreased with age. In the first year of the study (2006) the N content amounted to $2.29 \% \mathrm{DW}$ in orchard 1, and $2.37 \%$ DW in orchard 2. In the last year of the study (2010) the $\mathrm{N}$ content in the leaves of trees planted in orchard 1 (Tab. 4) and orchard 2 (Tab. 5) amounted to $22.05 \%$ and $2.11 \%$ DW, respectively. The optimal $\mathrm{N}$ content was in the younger orchard in 2006 and 2007, but it decreased to a low level in the subsequent years, as compared with the optimal ranges given by Sadowski et al. (1990) and by Komosa (2012). In our study the trees in orchard 1 had high leaf $\mathrm{N}$ content in 2006, but it decreased and remained at a lower level between 2007 and 2010 (Tab. 4). The results were in agreement with previous studies by Zydlik et al. (2006b) and Jadczuk and Sadowski (1997), who found the highest nitrogen content in the leaves of young trees.

The pruning method had no significant influence on the leaf P content (Tab. 3). However, it is noteworthy that regardless of the age of the orchard, a higher P content of was found in the control sample, where pruning was not applied. A higher but statistically insignificant difference was found in orchard 2 (Tab. 5). In comparison with the 20022005 tree growth period (Zydlik et al., 2006), the $\mathrm{P}$ content was significantly higher than in the next five years (2005-2010). In our research the average leaf $\mathrm{P}$ content was optimal when compared with the limit value ranges.

Like the $\mathrm{N}$ content, the leaf $\mathrm{K}$ content depended on the age of trees and it was higher in orchard 2 
Table 5. Effect of pruning on macro nutrients (\% DW) of in leaves of sour cherry trees planted in 2002

\begin{tabular}{|c|c|c|c|c|c|}
\hline \multirow{2}{*}{ Pruning } & \multicolumn{5}{|c|}{ Year of leaves analyses } \\
\hline & 2006 & 2007 & 2008 & 2009 & 2010 \\
\hline & \multicolumn{5}{|c|}{$\mathrm{N}$} \\
\hline Without cutting & $2.31 \mathrm{a}$ & $2.32 \mathrm{a}$ & $2.01 \mathrm{a}$ & $2.29 \mathrm{~b}$ & $1.94 \mathrm{a}$ \\
\hline Moderate traditional pruning & $2.43 \mathrm{~b}$ & $2.46 \mathrm{a}$ & $2.13 \mathrm{a}$ & $2.16 \mathrm{a}$ & $2.10 \mathrm{~b}$ \\
\hline Intensive pruning & $2.36 \mathrm{ab}$ & $2.39 \mathrm{a}$ & $2.32 \mathrm{~b}$ & $2.30 \mathrm{~b}$ & $2.28 \mathrm{c}$ \\
\hline \multirow[t]{2}{*}{ Mean of pruning } & $2.37 \mathrm{c}$ & $2.39 \mathrm{c}$ & $2.15 \mathrm{a}$ & $2.25 \mathrm{~b}$ & $2.11 \mathrm{a}$ \\
\hline & \multicolumn{5}{|c|}{$\mathrm{P}$} \\
\hline Without cutting & $0.17 \mathrm{a}$ & $0.21 \mathrm{a}$ & $0.28 \mathrm{a}$ & $0.35 \mathrm{a}$ & $0.29 \mathrm{a}$ \\
\hline Moderate traditional pruning & $0.19 \mathrm{a}$ & $0.24 \mathrm{a}$ & $0.24 \mathrm{a}$ & $0.28 \mathrm{a}$ & $0.26 \mathrm{a}$ \\
\hline Intensive pruning & $0.18 \mathrm{a}$ & $0.23 \mathrm{a}$ & $0.26 \mathrm{a}$ & $0.32 \mathrm{a}$ & $0.27 \mathrm{a}$ \\
\hline \multirow[t]{2}{*}{ Mean of pruning } & $0.18 \mathrm{a}$ & $0.23 \mathrm{~b}$ & $0.26 \mathrm{c}$ & $0.31 \mathrm{~d}$ & $0.27 \mathrm{c}$ \\
\hline & \multicolumn{5}{|c|}{$\mathrm{K}$} \\
\hline Without cutting & $0.87 \mathrm{a}$ & $1.05 \mathrm{a}$ & $1.10 \mathrm{a}$ & $1.53 \mathrm{a}$ & $1.19 \mathrm{a}$ \\
\hline Moderate traditional pruning & $0.88 \mathrm{a}$ & $1.18 \mathrm{a}$ & $1.01 \mathrm{a}$ & $1.29 \mathrm{a}$ & $1.33 \mathrm{a}$ \\
\hline Intensive pruning & $0.92 \mathrm{a}$ & $1.32 \mathrm{a}$ & $1.10 \mathrm{a}$ & $1.38 \mathrm{a}$ & $1.34 \mathrm{a}$ \\
\hline \multirow[t]{2}{*}{ Mean of pruning } & $0.89 \mathrm{a}$ & $1.18 \mathrm{bc}$ & $1.08 \mathrm{~b}$ & $1.38 \mathrm{~d}$ & $1.30 \mathrm{~cd}$ \\
\hline & \multicolumn{5}{|c|}{$\mathrm{Ca}$} \\
\hline Without cutting & $2.67 \mathrm{a}$ & $2.44 \mathrm{a}$ & $3.90 \mathrm{c}$ & $2.64 \mathrm{a}$ & $2.72 \mathrm{~b}$ \\
\hline Moderate traditional pruning & $2.36 \mathrm{a}$ & $2.37 \mathrm{a}$ & $3.50 \mathrm{~b}$ & $2.66 \mathrm{a}$ & $2.38 \mathrm{a}$ \\
\hline Intensive pruning & $2.38 \mathrm{a}$ & $2.37 \mathrm{a}$ & $2.95 \mathrm{a}$ & $2.71 \mathrm{a}$ & $2.32 \mathrm{a}$ \\
\hline \multirow[t]{2}{*}{ Mean of pruning } & $2.46 \mathrm{a}$ & $2.38 \mathrm{a}$ & $3.45 \mathrm{~b}$ & $2.66 \mathrm{a}$ & $2.47 \mathrm{a}$ \\
\hline & \multicolumn{5}{|c|}{$\mathrm{Mg}$} \\
\hline Without cutting & $0.55 \mathrm{a}$ & $0.58 \mathrm{ab}$ & $0.76 \mathrm{a}$ & $0.58 \mathrm{a}$ & $0.61 \mathrm{a}$ \\
\hline Moderate traditional pruning & $0.56 \mathrm{a}$ & $0.61 \mathrm{~b}$ & $0.72 \mathrm{a}$ & $0.58 \mathrm{a}$ & $0.57 \mathrm{a}$ \\
\hline Intensive pruning & $0.59 \mathrm{a}$ & $0.52 \mathrm{a}$ & $0.75 \mathrm{a}$ & $0.59 \mathrm{a}$ & $0.56 \mathrm{a}$ \\
\hline Mean of pruning & $0.56 \mathrm{a}$ & $0.57 \mathrm{a}$ & $0.74 \mathrm{~b}$ & $0.58 \mathrm{a}$ & $0.58 \mathrm{a}$ \\
\hline
\end{tabular}

"Means marked by the same letters are not significant at the $p \leq 0.05$

than in orchard 1. Intensive pruning increased the average leaf $\mathrm{K}$ content in orchard 2 (Tab. 3), but it did not influence the K content in orchard 1 (Tab. 4), where the yield was lower than in orchard 2. When compared with the applicable value ranges, the $\mathrm{K}$ content in 2009 and 2010 was optimal regardless of the orchard age and the growing season conditions. During the other growing seasons the K content was low (Sadowski et al., 1990; Komosa, 2012).

Tree pruning influenced the Ca content in sour cherry leaves. Moderate and intensive pruning significantly reduced the $\mathrm{Ca}$ leaf content in orchard 1 in 2008 and 2010 as well as the average value referring to all the research years. Likewise, the $\mathrm{Ca}$ leaf content was reduced in orchard 2, except for 2008. The Ca leaf content decreased as the pruning intensity increased. It reached the lowest level in the combinations where sprouts older than 3 years were removed. In the growing season of 2008 the $\mathrm{Ca}$ content in both plantations was significantly higher than in the other years (Tab. 6). However, for three months before the collection of leaf samples (MayJuly) the total rainfall was very low, i.e. $28.7 \mathrm{~mm}$, which could have influenced the $\mathrm{Ca}$ level. Pacholak et al. (2004) observed lower Ca concentration in leaves collected from irrigated plots.

The Mg content depended on the tree pruning intensity and the growing season conditions only in orchard 1. Intensive pruning resulted in a significantly lower $\mathrm{Mg}$ content. The $\mathrm{Mg}$ content in leaves also depended on the weather conditions during the growing season. In 2008 the leaf $\mathrm{Mg}$ content was the highest, i.e. $0.75 \%$ DW. In comparison with the optimal ranges, the $\mathrm{Mg}$ content was high and ranged from $0.52 \%$ to $0.79 \%$ DW (Tab. 4).

The analysis of the linear correlation between the weather conditions and the content of macronutrients as a mean of years showed the influence of climate on the content of macronutrients in sour cherry 
Table 6. Effect of pruning on percent of dry matter (\% DW) of macro nutrients in leaves of sour cherry trees (average of the 2001 and 2002 plantings)

\begin{tabular}{|c|c|c|c|c|c|}
\hline \multirow{2}{*}{ Pruning } & \multicolumn{5}{|c|}{ Year of leaves analyses } \\
\hline & 2006 & 2007 & 2008 & 2009 & 2010 \\
\hline & \multicolumn{5}{|c|}{$\mathrm{N}$} \\
\hline Without cutting & $2.27 \mathrm{a}$ & $2.26 \mathrm{a}$ & $2.02 \mathrm{a}$ & $2.27 \mathrm{a}$ & $1.95 \mathrm{a}$ \\
\hline Moderate traditional pruning & $2.38 \mathrm{~b}$ & $2.30 \mathrm{a}$ & $2.13 \mathrm{~b}$ & $2.16 \mathrm{a}$ & $2.09 \mathrm{~b}$ \\
\hline Intensive pruning & $2.35 \mathrm{ab}$ & $2.30 \mathrm{a}$ & $2.28 \mathrm{c}$ & $2.25 \mathrm{a}$ & $2.19 \mathrm{c}$ \\
\hline \multirow[t]{2}{*}{ Mean of year ${ }^{*}$} & $2.33 \mathrm{~d}$ & $2.28 \mathrm{~cd}$ & $2.14 \mathrm{~b}$ & $2.23 \mathrm{c}$ & $2.08 \mathrm{a}$ \\
\hline & \multicolumn{5}{|c|}{$\mathrm{P}$} \\
\hline Without cutting & $0.19 \mathrm{a}$ & $0.21 \mathrm{a}$ & $0.27 \mathrm{a}$ & $0.30 \mathrm{a}$ & $0.26 \mathrm{a}$ \\
\hline Moderate traditional pruning & $0.19 \mathrm{a}$ & $0.22 \mathrm{a}$ & $0.25 \mathrm{a}$ & $0.29 \mathrm{a}$ & $0.26 \mathrm{a}$ \\
\hline Intensive pruning & $0.19 \mathrm{a}$ & $0.22 \mathrm{a}$ & $0.26 \mathrm{a}$ & $0.29 \mathrm{a}$ & $0.24 \mathrm{a}$ \\
\hline \multirow[t]{2}{*}{ Mean of year } & $0.19 \mathrm{a}$ & $0.22 \mathrm{~b}$ & $0.26 \mathrm{c}$ & $0.29 \mathrm{~d}$ & $0.25 \mathrm{c}$ \\
\hline & \multicolumn{5}{|c|}{$\mathrm{K}$} \\
\hline Without cutting & $0.93 \mathrm{a}$ & $1.05 \mathrm{a}$ & $1.04 \mathrm{a}$ & $1.43 \mathrm{a}$ & $1.29 \mathrm{a}$ \\
\hline Moderate traditional pruning & $0.87 \mathrm{a}$ & $1.05 \mathrm{a}$ & $1.00 \mathrm{a}$ & $1.29 \mathrm{a}$ & $1.18 \mathrm{a}$ \\
\hline Intensive pruning & $0.94 \mathrm{a}$ & $1.17 \mathrm{a}$ & $1.12 \mathrm{a}$ & $1.33 \mathrm{a}$ & $1.28 \mathrm{a}$ \\
\hline \multirow[t]{2}{*}{ Mean of year } & $0.91 \mathrm{a}$ & $1.09 \mathrm{~b}$ & $1.05 \mathrm{~b}$ & $1.35 \mathrm{~d}$ & $1.25 \mathrm{c}$ \\
\hline & \multicolumn{5}{|c|}{$\mathrm{Ca}$} \\
\hline Without cutting & $2.51 \mathrm{a}$ & $2.33 \mathrm{a}$ & $3.37 \mathrm{a}$ & $2.63 \mathrm{a}$ & $2.72 \mathrm{~b}$ \\
\hline Moderate traditional pruning & $2.52 \mathrm{a}$ & $2.31 \mathrm{a}$ & $2.79 \mathrm{a}$ & $2.56 \mathrm{a}$ & $2.35 \mathrm{a}$ \\
\hline Intensive pruning & $2.61 \mathrm{a}$ & $2.28 \mathrm{a}$ & $3.33 \mathrm{a}$ & $2.60 \mathrm{a}$ & $2.29 \mathrm{a}$ \\
\hline \multirow[t]{2}{*}{ Mean of year } & $2.55 \mathrm{~b}$ & $2.31 \mathrm{a}$ & $3.17 \mathrm{c}$ & $2.60 \mathrm{~b}$ & $2.45 \mathrm{ab}$ \\
\hline & \multicolumn{5}{|c|}{$\mathrm{Mg}$} \\
\hline Without cutting & $0.59 \mathrm{a}$ & $0.57 \mathrm{ab}$ & $0.77 \mathrm{a}$ & $0.59 \mathrm{a}$ & $0.62 \mathrm{~b}$ \\
\hline Moderate traditional pruning & $0.59 \mathrm{a}$ & $0.59 \mathrm{~b}$ & $0.74 \mathrm{a}$ & $0.58 \mathrm{a}$ & $0.58 \mathrm{ab}$ \\
\hline Intensive pruning & $0.59 \mathrm{a}$ & $0.53 \mathrm{a}$ & $0.72 \mathrm{a}$ & $0.58 \mathrm{a}$ & $0.54 \mathrm{a}$ \\
\hline Mean of year & $0.59 \mathrm{a}$ & $0.56 \mathrm{a}$ & $0.74 \mathrm{~b}$ & $0.58 \mathrm{a}$ & $0.58 \mathrm{a}$ \\
\hline
\end{tabular}

*Means marked by the same letters are not significant at the $p \leq 0.05$

leaves. The total rainfall during the growing season was positively correlated with the leaf $\mathrm{K}$ and $\mathrm{P}$ content, but negatively correlated with the $\mathrm{Ca}$ and
$\mathrm{Mg}$ content. There was no significant correlation between the total rainfall and the $\mathrm{N}$ content in cherry trees (Tab. 7).

Table 7. Linear correlation $(\mathrm{N}=120)$ coefficients between environmental factors and content of $\mathrm{N}, \mathrm{P}$ and $\mathrm{Mg}$ in soil and the content of macro nutrients in leaves (average for of the plantings 2001 and 2002)

\begin{tabular}{lllllc}
\hline \multirow{2}{*}{ Parameter } & \multicolumn{4}{c}{ Content of mineral components in the leaves } \\
\cline { 2 - 6 } & $\mathrm{N}$ & $\mathrm{P}$ & $\mathrm{K}$ & $\mathrm{Ca}$ & $\mathrm{Mg}$ \\
\hline Average temperature (Apr-Sep) & +0.3172 & -0.2768 & -0.1238 & -0.2153 & -0.2703 \\
Minimum temperature Apr-Sep) & +0.3171 & $-0.5238^{* *}$ & $-0.5442^{* *}$ & +0.0201 & +0.0462 \\
Maximum temperature (Apr-Sep) & -0.2191 & $+0.4568^{*}$ & $+0.6014^{* *}$ & -0.2153 & -0.2492 \\
Sum of precipitation (Apr-Sep) & +0.0045 & $+0.3799^{*}$ & $+0.5622^{* *}$ & $-0.3972^{*}$ & $-0.4273^{*}$ \\
\hline Yield & $+0.2615^{* *}$ & +0.1087 & +0.0269 & +0.1652 & +0.1269 \\
\hline & & Content of mineral components in the soil & \\
P & +0.0961 & -0.1117 & $-0.2523^{* *}$ & +0.0244 & +0.0300 \\
$\mathrm{~K}$ & $+0.2224^{*}$ & +0.0113 & +0.0566 & $+0.1949 *$ & -0.0173 \\
$\mathrm{Mg}$ & $-0.3897^{* *}$ & $+0.4400^{* *}$ & $+0.1975^{*}$ & $+0.2022^{*}$ & +0.1520 \\
\hline
\end{tabular}

$* *, *$ significant at $p \leq 0.01$ and 0.05 , respectively 
The average temperature during the growing season did not have significant influence on tree nutrition. However, low temperatures between April and September negatively influenced the leaf $\mathrm{K}$ and $\mathrm{P}$ content. The nitrogen uptake did not depend on higher temperatures during the growing season. There were similar trends in the $\mathrm{Ca}$ and $\mathrm{Mg}$ content (Tab. 7).

According to Roversi et al. (2008), the content of nutrients in soil does not generally influence the content of elements in cherry tree leaves. Thus, an increase in the content of potassium in soil did not increase the content of $\mathrm{N}, \mathrm{P}, \mathrm{K}, \mathrm{Ca}$ or $\mathrm{Mg}$ in apple tree leaves (Szewczuk et al., 2011). However, in our study the $\mathrm{P}$ content in soil was negatively correlated with the leaf K content (Tab. 7). Nevertheless, there was a positive correlation between the soil $\mathrm{K}$ content and the $\mathrm{N}$ and $\mathrm{Ca}$ content in leaves. An increase in the $\mathrm{Mg}$ content in soil had negative influence on the $\mathrm{N}$ content in leaves, but positive influence on the $\mathrm{P}$, $\mathrm{K}$, and $\mathrm{Ca}$ content in leaves.

\section{CONCLUSIONS}

1. Intensive pruning by removing branches older than 3 years and pruning by shortening branches of 'Łutówka' sour cherry trees by a third of their length resulted in good nutrition of trees. However, the leaf $\mathrm{Ca}$ and $\mathrm{Mg}$ content was reduced.

2. High temperatures at the beginning of the growth season are particularly beneficial. Cold and dry spring limits the $\mathrm{P}$ and $\mathrm{K}$ content in cherry trees. Therefore, during the period of considerably lower temperatures or drought it is necessary to supply nutrients by spraying foliar fertilisers.

3. The mineral content in sour cherry leaves depends on the age of trees.

\section{FUNDING}

The research was funded by the Poznan University of Life Sciences.

\section{AUTHOR CONTRIBUTIONS}

K.R. - contributed to the entire experimental process, collected and analysed data, interpreted, searched literature and wrote the paper; Z.Z. collected and analysed the data; A.S. - contributed to manuscript writing.

\section{CONFLICT OF INTEREST}

Authors declare no conflict of interest.

\section{REFERENCES}

Brzozowski P., ZMARLicki K., 2011. The own and hired labour inputs on farms with apple and sour cherry production versus the volume and profitability of that production. Zesz. Nauk. Inst. Sadow. Kwiac. 19, 2241.

Dencker I., Toldam-Andersen T.B., 2005. Effects of rootstock, winter temperature, and potassium fertilization on yield components of young sour cherries. Acta Hortic. 667, 409-414.

Food and Agriculture Organization of the United NATiOns (FAO), 2014. FAOSTAT: Cherries sour. http://www.fao.org/faostat/en/\#data/QC. Accessed 5 November 2017.

GUS, 2016. Statistical Yearbook of Agriculture. Cent. Stat. Off. Pol. Wars.

Нrотко́ K., 2013. Development of fruit trees production systems. AgroLife Sci. J. (2)1, 28-35.

Hrotkó K., Csigai K., Magyar L., Hrotkó V., 2008. Productivity of fruiting wood on slender spindle sour cherry trees. Acta Hortic. 795( 1-2), 503-507.

Jiménez S., Pinochet J., Gogorcena Y., Betran J.A., Moreno M.A., 2007. Influence of different vigor cherry rootstocks on leaves and shoots mineral composition. Sci. Hort. 112, 73-79.

Komosa A., 2012. Żywienie roślin ogrodniczych. PWRiL, Warszawa, Poland.

KRISHKOV E., 2007. Impact of preplanting fertilization on the leaf nutrient content of young sour cherry trees. Not. Bot. Horti. Agrobo. 35(2), 76-81.

Lang G., Valentino T., Robinson T.L., Freer J., Larsen, H., Pokharel R., 2011. Differences in mineral nutrient concentration of dormant cherry spurs as affected by rootstock, scion, and orchard site. Acta Hortic. 903, 963-971.

Mestre L., Reig G., Betran J.A., Moreno M.A., 2017. Influence of plum rootstocks on agronomic performance, leaf mineral nutrition and fruit quality of 'Catherina' peach cultivar in heavy-calcareous soil conditions. Span. J. Agric. Res. 15(1), 1-11.

Mika A., Buler Z., Michalska B., 2011a. Biology of flowering and fruiting of sour cherry trees growth at high density. J. Fruit Ornam. Plant Res. 19 (1), 123136.

Mika A., Wawrzyńczak P., Buler Z., Krawiec A., Biąkowski P., Michalska B., Plaskota M., Gotowicki B., 2011b. Result of experiments with densely planted sour cherry trees for harvesting with a continuously moving combine harvester. J. Fruit Ornam. Plant Res. 19(2), 31-40.

Mikiciuk G., Możdżer E., Mikiciuk M., CheŁpińsKi P., 2013. The effect of antitranspirant on the content of microelements and trace elements in sweet cherry leaves and fruits. J. Ecol. Eng. 14(4), 36-38.

MilošEvić T., MiLoŠEvić N., Glišić I., 2012. Vegetative growth, fruit weight, and leaf mineral contentof plum grown on acid soil. J. Plant Nutr. 35(5), 770-783. 
Nagy P.T., Thurzó S., RACskó J., NyÉKi J., SOltÉSZ M., Szabó Z., 2007. Effect of different flower thinning techniques on annual fluctuation of macro and micronutrients in sweet cherries (Prunus avium L.). Int. J. Hort. Sci. 13(3), 87-90.

Ostrowska A., Gawliński S., SzczubiaŁka Z., 1991. Metody analizy i oceny właściwości gleb i roślin. Instytut Ochrony Środowiska, Warszawa, Poland.

Pacholak E., Zydlik Z., Zachwieja M., 2004. The effect of irrigation and methods of soil exhaustion prevention on nutrient contents in the soil and leaves. J. Fruit Ornam. Plant Res. 12, 69-81.

Pietranek A., Jadczuk E., 2005: Mineral status of 'Katja' apple trees depending on irrigation, fertilization and rootstock. Acta Sci. Pol., Hortorum Cultus 4(1), 69-76.

Roversi A., Ughini V., Monteforte A., 2008. Influence of genotype, year and soil composition on sweet cherry leaf mineral composition. Acta Hortic. 795, 739-746.

Rowley S.D., 2013. Phosphorus and potassium fertility management for maximizing tart cherry fruit quality and productivity on alkaline soils. Retrieved from All Graduate Theses and Dissertations. Paper 1518. http:// digitalcommons.usu.edu/etd/1518.

Rutkowski K., Zydlik Z., Pacholak E., 2015. Effect of tree pruning intensity on the yield and fruit quality of the sour cherry. Zemdyrbiste-Agriculture 102(4), 417-422.

Sadowski A., Nurzyński J., Pacholak E., Smolarz K., 1990. Określenie potrzeb nawożenia roślin sadowniczych. II. Zasady, liczby graniczne i dawki nawożenia. Instrukcja upowszechnieniowa 3, Warszawa: 6-9.

JADCZuK E., SADOWSKi A., 1997. Nutritional status of 'Schattenmorelle' cherry trees in relation to the type of root system and tree age. Acta Hortic. 448, 137-144.

Szewczuk A., Komosa A., Gudarowska E., 2011: Effect of soil potasium levels and different potassium fertilizers on yield, macroelement and chloride nutrion status of apple trees in full fruition period. Acta Sci. Pol., Hortorum Cultus 10(1), 83-94.

Treder W., Olszewski T., 2004. The estimation of the influence of the way of fertilization on the content of nitrogen in the leaves of apple trees. Acta Sci. Pol., Hortorum Cultus 3(2), 111-122.

Tsai E., 2015. Validation of tissue nutrient status for tart cherry (Prunus cerasus) and peach (Prunus persica) in Utah. Utah State University, MS Thesis.

Zydlik Z., PaCholak E., ZaChwieja M., RutKowski K., 2006a. Effect of nitrogen fertilization on mineral components content in sour cherry tree leaves. PTPN, Publications of the Forestry and Agricultural Sciences Committee, 100, 303-310.

Zydlik Z., Pacholak E., Zachwieja Z., Rutkowski K., 2006b. Effect of crown formation on the content of mineral components in sour cherry-tree leaves. Publications of the Forestry and Agricultural Sciences Committee, 100, 311-316.

Zydlik Z., Pacholak E., 2007. Effect of soil locality on the growth and content of mineral components in M.9 rootstock. Acta Sci. Pol., Hortorum Cultus 6(4), 11-20.

Received February 20, 2017; accepted December 20, 2017 